\title{
Current status of Marsh Crocodiles Crocodylus palustris (Reptilia: Crocodylidae) in Vishwamitri River, Vadodara City, Gujarat, India
}

\author{
Raju Vyas \\ 505, Krishnadeep Tower, Mission Road, Fatehgunj, Vadodara, Gujarat 390002, India \\ Email: razoovyas@hotmail.com
}

\begin{abstract}
Data presented here is based on a three year study (2008-2010) on a population of Mugger Crocodylus palustris inhabiting Vishwamitri River near Vadodara City, Gujarat State, India. In total, 155 Muggers were counted in the $25 \mathrm{~km}$ river stretch during 2010. In all, 40 burrows were observed along the river bank, and the same were clumped in certain sections of the river. Muggers fed eight species of birds, and domestic livestock in addition to scavenging. Eight instances of human-crocodile conflicts were observed including four human causalities. A tota 90 Muggers were rescued from the urban areas and the same were relocated elsewhere in the river system. Various types of threats to Mugger were also noticed including habitat loss, alteration and soil erosion and mortality due to rail traffic. The present study suggests further research to propose strategies to conserve this population.
\end{abstract}

Keywords: Mugger-human conflicts, rescue, river system, translocation, urban area.

Date of publication (online): 26 November 2012

Date of publication (print): 26 November 2012

ISSN 0974-7907 (online) | 0974-7893 (print)

Editor: S. Bhupathy

Manuscript details:

Ms \# 02977

Received 26 October 2011

Final received 05 October 2012

Finally accepted 20 October 2012

Citation: Vyas, R. (2012). Current status of Marsh Crocodiles Crocodylus palustris (Reptilia: Crocodylidae) in Vishwamitri River, Vadodara City, Gujarat, India. Journal of Threatened Taxa 4(14): 3333-3341

Copyright: @ Raju Vyas 2012. Creative Commons Attribution 3.0 Unported License. JoTT allows unrestricted use of this article in any medium for nonprofit purposes, reproduction and distribution by providing adequate credit to the authors and the source of publication.

Acknowledgements: I am thankful to all staff members of NGOs and government organization listed in Appendix 2, for the help in various aspects of study and survey. Special thanks to the Conservator of Forest, Social Forestry, Vadodara for the help in survey. I am especially thankful to Mrs. Snehal Bhavsar, Rajesh Bhavsar, Manoj Thakar, Vishal Thakor, Viral Roy, Pritesh Patel and Kartik Upadhayay for providing photographs for the article and accompanying me during the field work. Finally, I am grateful to Khushboo R. Vyas for reviewing the draft manuscript.

urn:Isid:zoobank.org:pub:23DA3FAB-C113-4008-A8C4-1CDD4E92EAFB

\section{OPEN ACGESS | FREE DOWNLOAD}

The Marsh Crocodile or Mugger Crocodylus palustris is one of the common and wide spread crocodilian species in India. This species is categorized as nationally 'Vulnerable' subsequent to an assessment following IUCN criteria for threatened species (Molur \& Walker 1998) and has the highest legal protection in India as it is listed in Schedule I of the Indian Wildlife (Protection) Act 1972. During the early seventies, while the Mugger populations in India were reportedly declining (Whitaker \& Andrews 2003), Oza (1975) reported over 50 individuals of this species in Sayaji Sarovar (Ajwa Village) in close vicinity to Vadodara City, Gujarat. This population has reportedly declined due to hunting and illegal fishing in the down-stream of River Vishwamitri (Vyas \& Vyas 2002; Vyas 2010a). The present study was carried out between January 2008 and December 2010 to determine its current status and assess issues related to conservation.

\section{Materials and Methods}

Study Area: The present study was conducted in a $25 \mathrm{~km}$ long and 40-60 m wide stretch of Vishwamitri River (from Vemali Village to Vadsar Bridge Vadodara City). The river flows through Vadodara City from north to south (Image 1) and it carries a significant quantum of sewage from the city and effluents from the Gujarat Industrial Development Corporations of Kalali and Makarpura. The downstream of the river is highly polluted (Gujarat Pollution Board 2007-08) and the water color varied from dark green-black-pink to red with a putrefied smell. The river stretch was divided into four sections based on the development of the city (Appendix 1) and river bank for easy approach. The section-wise features of the river and general information are available in Vyas (2010b).

Mugger count: Muggers were counted (visually) during December 2008-January 2009 and night surveys 


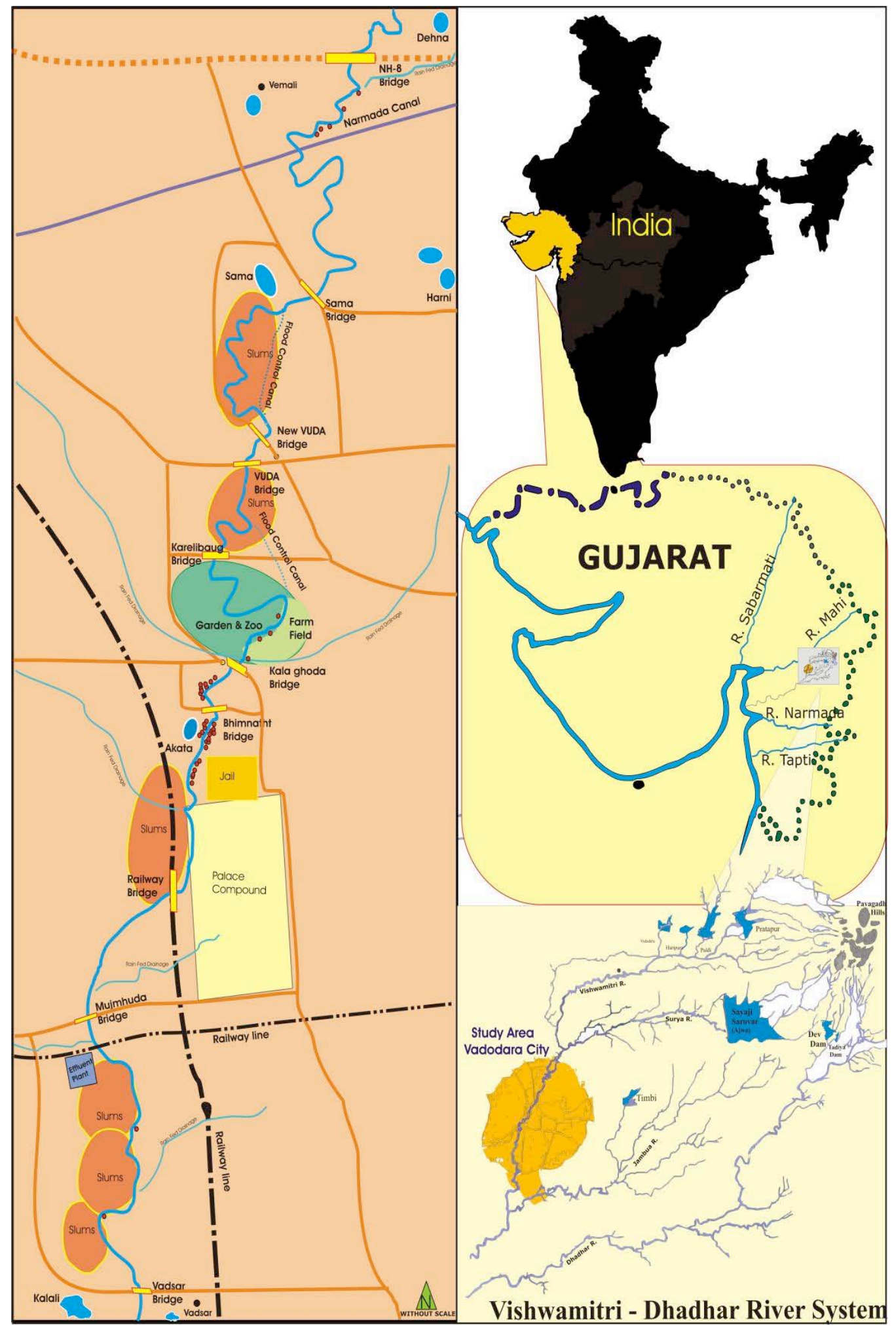

Image 1. Map of the study area: Vishwamitri River stretch and Vadodara City.

were done during January 2010 following Choudhary \& Rao (1982) and De Vos (1982). Basking animals were counted from vantage points on the river bank during mid-day using a pair of binoculars $(8 \mathrm{x} 40)$. Size class of the Muggers, shore and river bank features and river conditions were assessed visually. Mugger counts 
during night were done using a search light. These counts were carried out in the last week of January 2010 involving the staff of Gujarat Forest Department and volunteers of a few local non governmental organizations (Appendix 2). Prior to initiating these counts, an orientation routine was conducted for all team members briefing them on methodology. Most of the Muggers were recorded following eye reflection. Data such as size, habitat type, water quality, river side features, and anthropogenic activities in the area were recorded visually and man-animal conflicts were recorded opportunistically.

Burrow count: Mugger burrows were located manually during November 2008-January 2009. Burrows were categorised as active and inactive (abandoned) based on signs during repeated surveys.

\section{Results}

Mugger count 2008-09: Counts of Muggers during the day were carried out from the last week of December 2008 to January 2009. In total, 81 Muggers were counted within the $25 \mathrm{~km}$ stretch of the river studied. This included 14 juveniles, 24 subadults and 43 adults (over two meters). Data on Mugger counts at each section of the river and size class are given in Table 1. The highest of 36 Muggers was observed in river Section-2.

Mugger count 2010: During the night count, a total of 155 Muggers were observed, which included 78 adults. Section wise counts and size of Muggers are given in Table 1.

Burrows count: In total, 40 burrows of Muggers were observed during November 2008-January 2009, including 25 on the left bank and the rest on the right bank of the river. Among them, 36 burrows were active (Table 2). The highest of 27 active burrows were observed in Section-3. Only two burrows were recorded in Section-4, the down-stream of the river.

A River Front Project was initiated during 2009 by the Vadodara Municipal Corporation. In the first phase, the river banks were cleared and widened to facilitate the flow of water. Due to this, about $25 \%$ of burrows got blocked with loose soil. However, it was observed that within a few weeks the Muggers had excavated new burrows nearby.

Food and feeding: It was found that Muggers actively foraged nocturnally (dusk to dawn). During the study, Muggers were observed feeding on eight

Table 2. Numbers of burrows observed in study area, River Vishwamitri.

\begin{tabular}{|l|c|c|c|}
\hline Section no. & \multicolumn{3}{|c|}{ Number of Burrows } \\
\hline & Right Bank & Left Bank & Total \\
\hline & $\begin{array}{c}\text { Used }+ \\
\text { Unused }=\text { Total }\end{array}$ & $\begin{array}{c}\text { Used }+ \\
\text { Unused }=\text { Total }\end{array}$ & $\begin{array}{c}\text { Used }+ \\
\text { Unused }=\text { Total }\end{array}$ \\
\hline Section-I & $0+0=00$ & $3+2=05$ & $3+2=05$ \\
\hline Section- II & $1+0=01$ & $03+0=03$ & $04+0=04$ \\
\hline Section- III & $13+1=14$ & $14+1=15$ & $27+2=29$ \\
\hline Section- VI & $0+0=00$ & $02+0=02$ & $02+0=02$ \\
\hline Total & $14+1=15$ & $22+3=25$ & $36+4=40$ \\
\hline
\end{tabular}

Table 1. The Vishwamitri River section and count of Mugger Crocodylus palustris

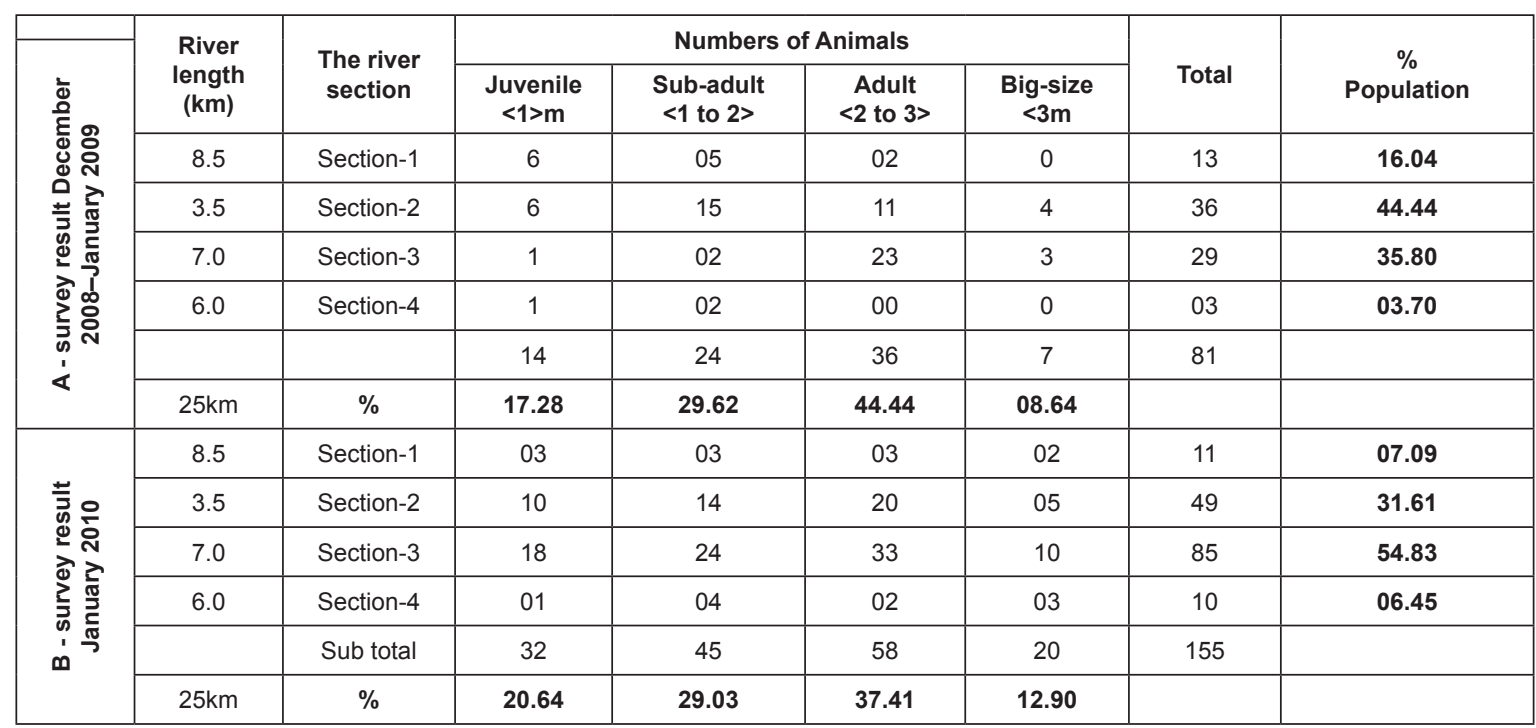


species of birds: Little Cormorant Phalacrocorax niger, Indian Pond Heron Ardeola grayii, Cattle Egret Bubulcus ibis, Night Heron Nycticorax nycticorax, Red-wattled Lapwing Vanellus indicus, Black-winged Stilt Himantopus himantopus, White-breasted Waterhen Amauronis phoenicurus and Blue Rock Pigeon Columba livia. Juveniles fed on frogs (Indian Skipping Frog Euphlyctis cyanophlyctis, Indian Bull Frog Hoplobatrachus tigerinus) and invertebrates such as insects and dragon flies.

During this study, Muggers attacking domestic animals such as goats, dogs and poultry were reported on numerous occasions, which indicate dependency of this species on domestic livestock for food. Muggers also scavenged on materials dumped in the river and on its banks (Image 2). On two occasions, this species was found scavenging on human carcasses and human foetuses thrown in to the river, probably by hospitals indicating that the river is being used for dumping medical wastes as well.

Human-Mugger conflicts: Muggers attacking people were observed on eight occasions during 2008-2010; Five male victims, including a 12-year old boy and three females of age group of 20-40 years were victims. Two attacks were noted within the city limits and the rest (6) along the down stream of river Dhadhar-Vishwamitri. Six attacks happened while the victims were crossing the river and in the other two cases it was while washing clothes and operating a motor for pumping water. Barring one record during April, all the other conflicts were observed during

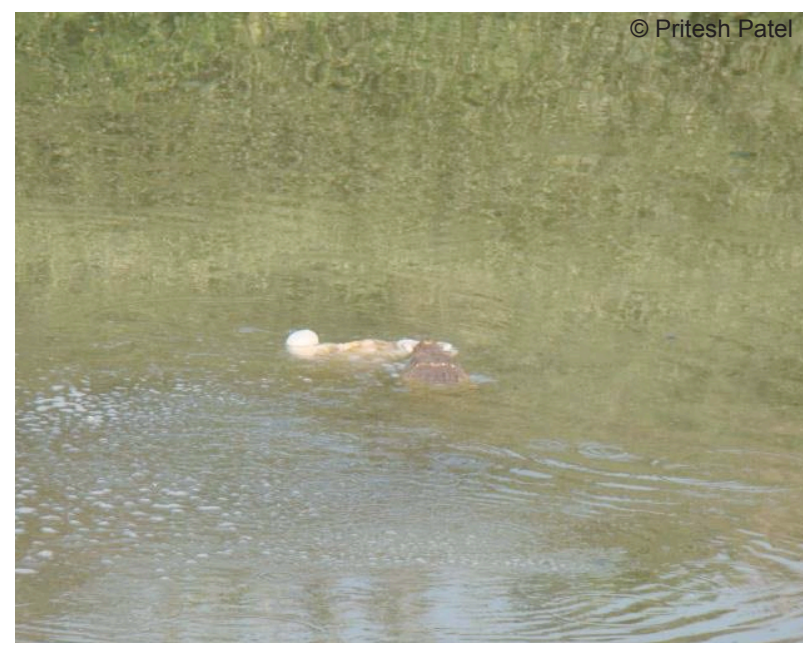

Image 2. A large Mugger crocodile feeding on an animal carcass
June-September.

Rescues: A total of 90 Muggers were rescued during this study including 25 juveniles, 25 subadults, 27 adults (13 muggers measured over three meter) (Fig. 1; Images $3 \& 4$ ). Monthly data showed that a higher number of Muggers were rescued during September, August and November (Fig. 2). The rescued crocodiles were sent to the Forest Department for release in suitable habitats. Prior to January 2009, the rescued crocodiles were released at Sayaji Sarovar, Ajwa Village and those rescued in subsequent years were released in the downstream of Vishwamitri River.

Nest and nesting success: Nine nests were recorded in Section-3 of the river from 2008-2010; of them, five nests were predated and hatchlings emerged successfully from the other four. However, hatchlings and juveniles contributed about $17 \%$ and $20 \%$ of the sampled population during 2009 and 2010, respectively. Of the three nests observed during 2009, 22 hatchlings emerged from two nests, found in Section-3 of the river (Image 5).

Threats: Threats to crocodiles include loss,

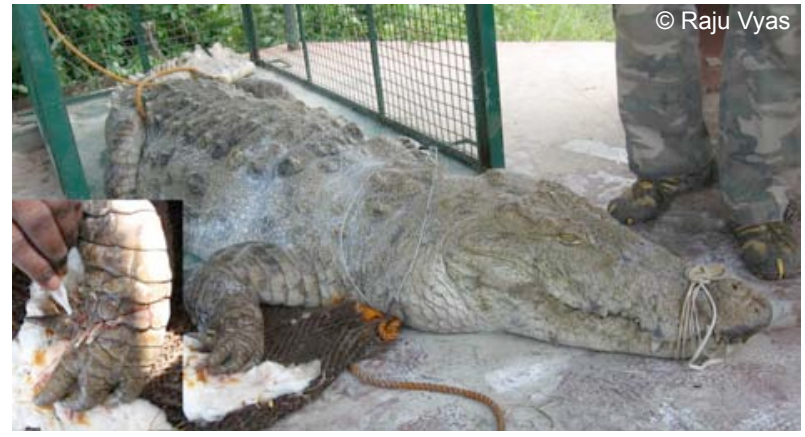

Image 3. A rescued Mugger with injury, inset close-up of injured foot.

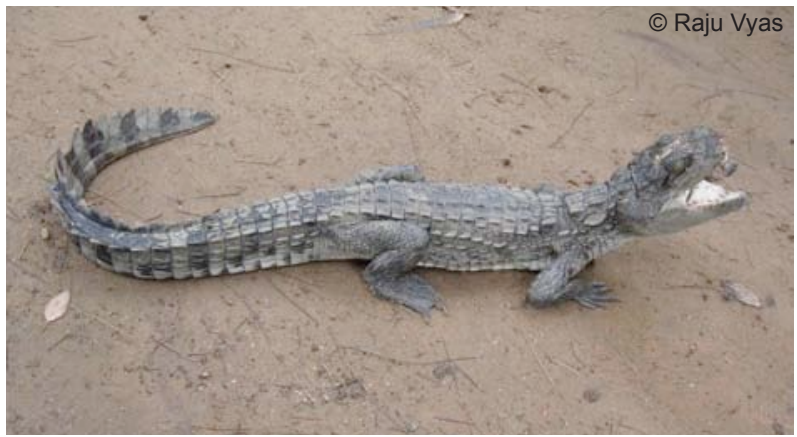

Image 4. An injured juvenile Mugger rescued from the Vadodara City. 

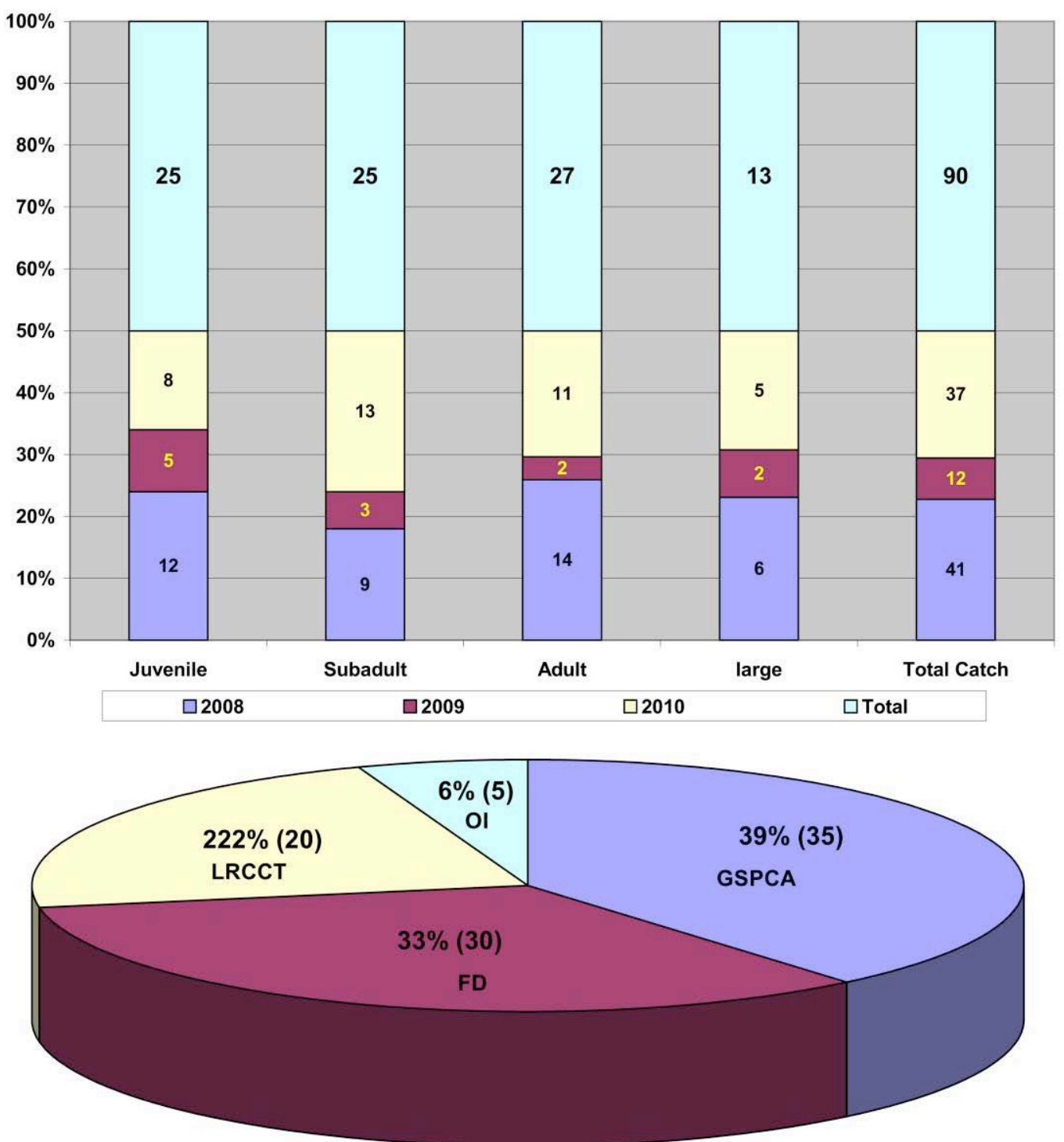

Figure 1. Size class of Muggers rescued from Vadodara City during 2008-2010 by Forest Department (FD)) and Non Governmental Organizations.

GSPCA - Gujarat Society for the Prevention of Cruelty to the Animals; LRCCT - Let. Rohan Crocodile Charitable Trust; OI - Others Individuals).

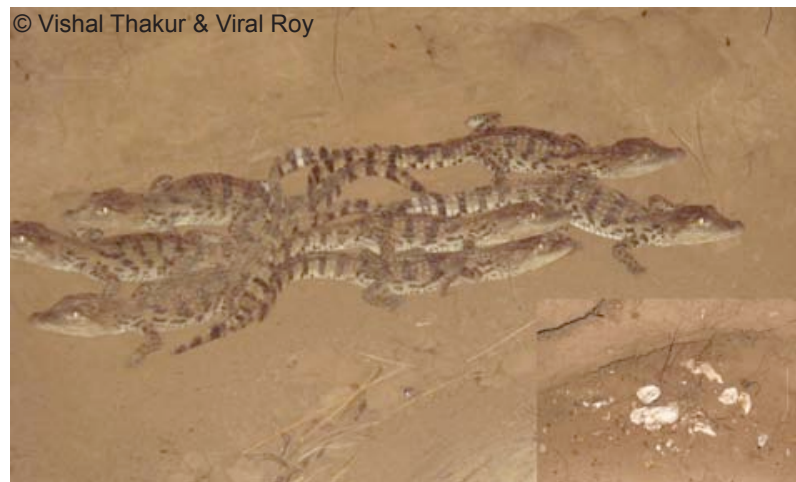

Image 5. Mugger hatchlings.

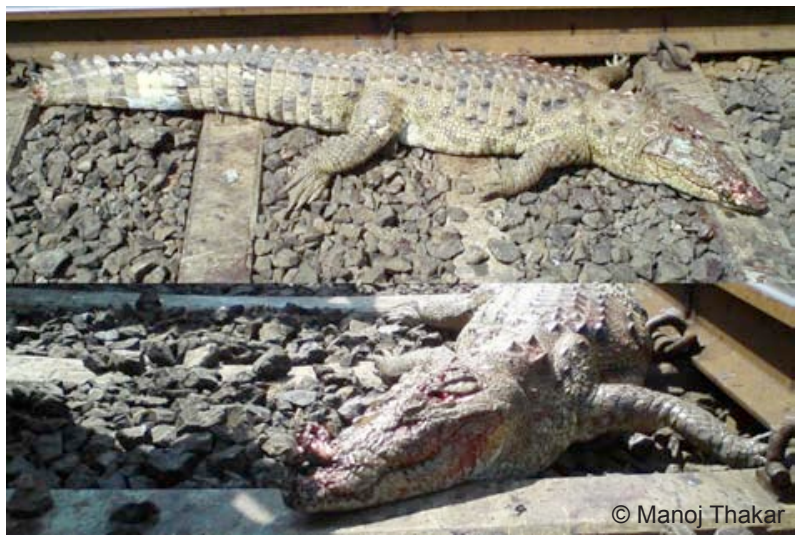

Image 6. An adult Mugger killed by rail traffic near Vishwamitri Railway Station, Vadodara 


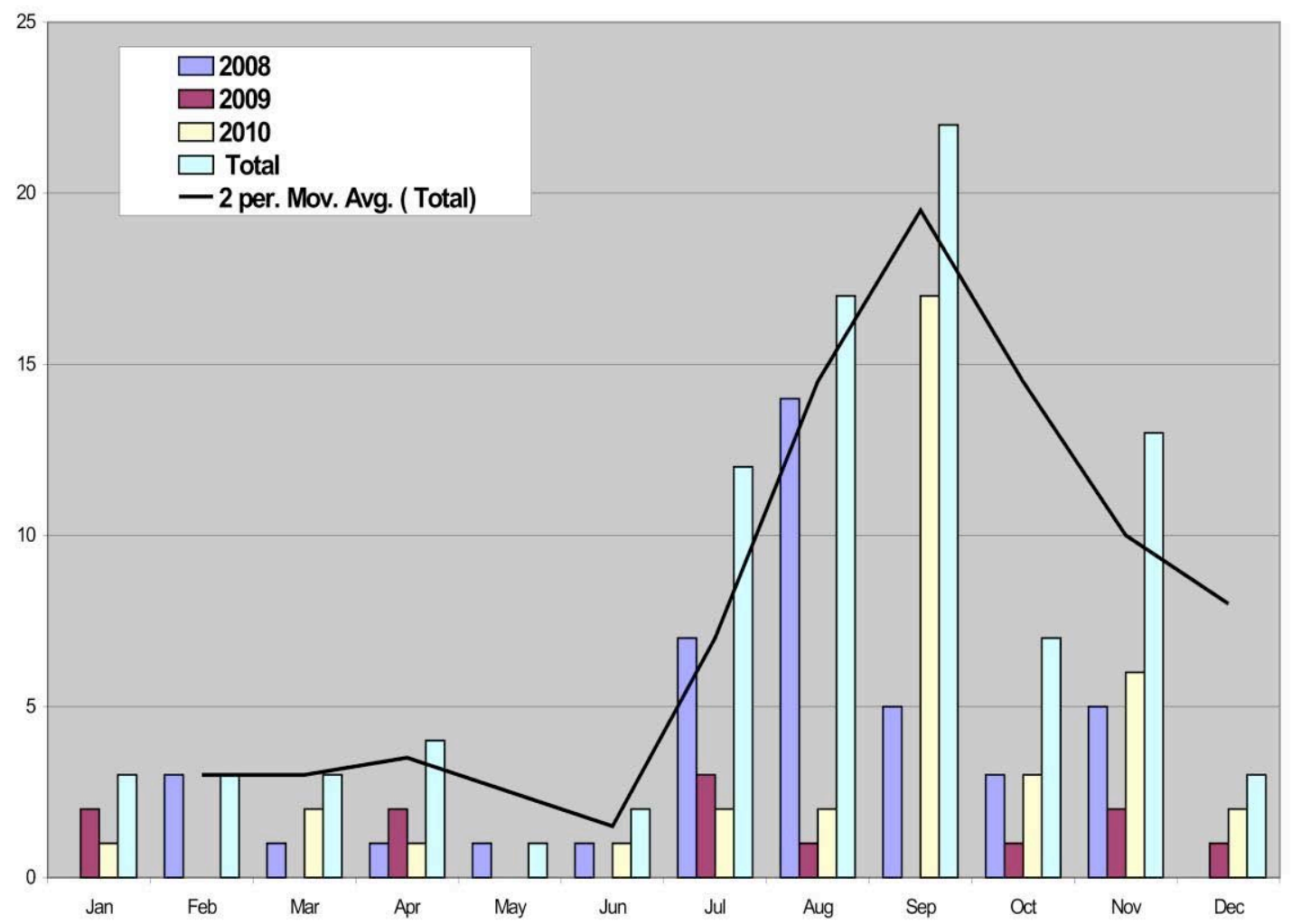

Figure 2. Mugger rescue in different months from Vadodara City during 2008 to 2010.

alteration and erosion of habitats, along with new developments in the river and its close vicinity. Recently, a few Muggers were killed in road and rail traffic (Image 6).

\section{Discussion}

Muggers in river Vishwamitri is one unique example of man living in harmony with animals. The two decades of Mugger count has shown an increasing trend in its population. Data on the status of Muggers of river Vishwamitri during January 1987 to December 2007 is summarized in Vyas (2010a). The 'night count' is relatively a better method to assess the population of Mugger compared to surveys during day.

A total of 40 burrows were counted in 2009, of which 36 were active. Among them, the highest number of 29 burrows and 26 animals was observed in Section-3 of the river. The number of burrows positively corresponded with the number of animals counted in the same river section. This is similar to the report by Nathalie (2011) on C. niloticus in River Tapoa, Niger. Prior to 1995 , there were only nine burrows along this river stretch (Vyas 2010b), which increased four fold during this study. During the riverfront project about
$25 \%$ burrows were damaged, but new burrows within a few weeks shows the adaptability of Muggers with respect to a changing environment.

Nonperennial and polluted rivers in general do not support rich fish fauna round the year. Therefore, crocodiles were forced to feed on various species, both live and dead animals. Observations of crocodiles feeding on discarded medical wastes such as human body parts and foetuses are alarming and this should be stopped.

Most of the human-crocodile conflict was observed during June-September, which is the breeding season of the species (Vijaykumar 1997). Crocodiles are known to be aggressive during the breeding season and often attack the intruder. Including the present study, a total of 22 attacks have been reported from 1985 to 2010 (Vyas 1993, 2005, 2010a; Whitaker 2008). The trend in Mugger attacking humans has increased over the years (Fig. 3), which requires attention of the concerned department, and further study is required to propose mitigation plans.

Mugger counts during 2010 showed adult crocodiles over two meters contributed about $50 \%$, which indicates a healthy population of this species 


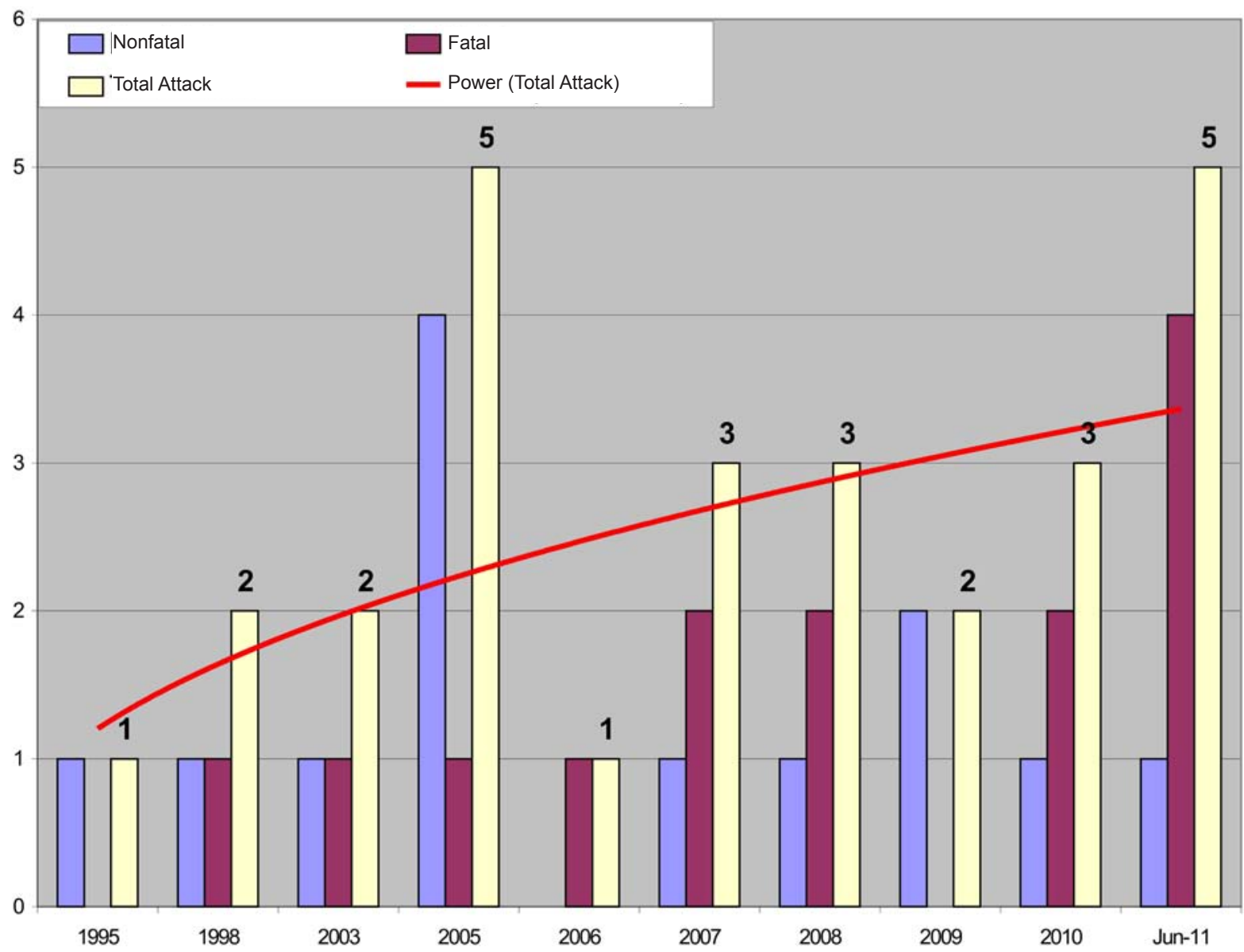

Figure 3. The trend in Mugger attacking humans has increased over the year, Vishvamitri River System, Gujarat, India.

in Vishwamitri River. However, continuous increase of a largely carnivorous species in close proximity to human habitation is a matter of concern. It is high time to design an action plan for this species at the state level and to evaluate the existing conservation strategy and reformulate the policies (Vyas 2010a), if required. Every year numerous Muggers are being rescued from urban areas of the city and translocated with the involvement of various NGOs and staff of the State Forest Department. While the interest of locals in crocodilian conservation is appreciable, lack of appropriate 'rescue and release' protocols is a matter of concern. A few translocated animals returned to the same river stretch from where they had been rescued earlier (Bhatt 2000; Vyas 2010b). Appropriate measures should be taken to protect Muggers from getting killed by vehicular traffic such as rail and road (Vyas \& Bhavsar 2009; Vyas 2011), which are new threats faced by this species.

This small and dense population of Mugger survives in the kernel of Vadodara, Gujarat, India is a notable example of crocodilian conservation and man-mugger concordance. The preservation of this population now lies in the hands of the residents of Vadodara City and various local government agencies, including the State Forest Department, Urban Development Authority and Municipal Corporation, Vadodara. Continuous monitoring of the population of this species is required as suggested by Vyas (2010a).

\section{REFERENCES}

Bhatt, S. (2000). Croc recaptured on Gujarat, CSG Newsletter 19(1): 9-10.

Choudhary, B.C. \& R.J. Rao (1982). Status survey of Crocodile population, 44-46. In: Captive management of crocodiles in India: A field Guide. Central Crocodile Breeding and Management, Training Institute, Hyderabad.

De Vos, A. (1982). A Manual on Crocodile Conservation and Management in India. Foods and Agricultural Organization 
Appendix 1. Segment studied in Vishwamitri River and description of the area and characteristics of river banks

\begin{tabular}{|c|c|c|c|c|c|}
\hline $\begin{array}{l}\text { River } \\
\text { Segment }\end{array}$ & $\begin{array}{l}\text { Boundary of the } \\
\text { River Segment }\end{array}$ & Co-ordinates & $\begin{array}{c}\text { Segment } \\
\text { length }\end{array}$ & Features of the river Bank & Activities \\
\hline Section-1 & $\begin{array}{l}\text { NH-No. } 8 \text { Bridge to } \\
\text { VUDA Circle } \\
\text { + Flood Control } \\
\text { Canal }\end{array}$ & $\begin{array}{l}73^{0} 12^{\prime} 48.67 ” \mathrm{E} \\
22^{0} 21^{\prime} 25.67 " \mathrm{~N} \\
\\
73^{0} 11^{\prime} 42.611^{\prime \prime} \mathrm{E} \\
22^{0} 19^{\prime} 30.23^{\prime \prime} \mathrm{N}\end{array}$ & $\begin{array}{c}8.5 \mathrm{~km} \\
(+1.0 \mathrm{~km})\end{array}$ & $\begin{array}{l}\text { The river bank is undisturbed and covered with } \\
\text { distant agricultural fields, and southwards near } \\
\text { Sama Village and VUDA circle area are the } \\
\text { recently developed urban residential societies, } \\
\text { EME school and training campus and a few } \\
\text { slums. }\end{array}$ & $\begin{array}{l}\text { Fishing, washing and } \\
\text { bathing. Also, river water } \\
\text { is used by farmers for } \\
\text { irrigation and a number } \\
\text { of illegal liquor distilleries } \\
\text { are operated on the } \\
\text { banks }\end{array}$ \\
\hline Section-2 & $\begin{array}{l}\text { VUDA Circle to } \\
\text { Kalaghoda Circle } \\
+ \text { Flood Control } \\
\text { Canal }\end{array}$ & $\begin{array}{l}73^{0} 11^{\prime} 42.61 ” \mathrm{E} \\
22^{0} 19^{\prime} 30.23 ” \mathrm{~N} \\
\\
73^{0} 11^{\prime} 20.18 ” \mathrm{E} \\
22^{0} 18^{\prime} 29.66 ” \mathrm{~N}\end{array}$ & $\begin{array}{c}3.5 \mathrm{~km} \\
(+1.0 \mathrm{~km})\end{array}$ & $\begin{array}{l}\text { The river banks are covered with slums, } \\
\text { gardens and zoo and urban residential } \\
\text { societies. } \\
\text { One drainage (Bhukhi) empties on the left } \\
\text { banks, which comes from the eastern side } \\
\text { areas of Chhani and Nizampura and the } \\
\text { second drainage drains on the right bank, from } \\
\text { the north-western slopes of city. }\end{array}$ & $\begin{array}{l}\text { Washing, bathing and } \\
\text { some illegal distilleries } \\
\text { are observed in this } \\
\text { segment too. Most of the } \\
\text { banks areas are used } \\
\text { by the slum dwellers for } \\
\text { defecation. }\end{array}$ \\
\hline Section-3 & $\begin{array}{l}\text { Kalaghoda Circle to } \\
\text { Munj Mahuda Bridge }\end{array}$ & $\begin{array}{l}73^{0} 11 ' 20.18 ” \mathrm{E} \\
22^{0} 18^{\prime} 29.66 ” \mathrm{~N} \\
\\
73^{0} 11^{\prime} 16.70 ” \mathrm{E} \\
22^{0} 17^{\prime} 08.03^{\prime \prime} \mathrm{N}\end{array}$ & $7.0 \mathrm{~km}$ & $\begin{array}{l}\text { Both the banks are covered with slums, open } \\
\text { scrub lands and a few residential societies. } \\
\text { Left banks open scrub lands and society. } \\
\text { One drainage pours into the right bank, which } \\
\text { comes from Akota area of city and the second } \\
\text { drainage empties into the left bank of the river, } \\
\text { this drainage assembles rain water from the } \\
\text { palace compound and city area. }\end{array}$ & $\begin{array}{l}\text { Washing and a few illegal } \\
\text { distilleries are operated } \\
\text { on the banks }\end{array}$ \\
\hline Section-4 & $\begin{array}{l}\text { Munj Mahuda Bridge } \\
\text { to Vadsar Bridge }\end{array}$ & $\begin{array}{l}73^{0} 11^{\prime} 16.70 ” \mathrm{E} \\
22^{0} 17^{\prime} 08.03^{\prime \prime} \mathrm{N} \\
73^{0} 10^{\prime} 07.72 ” \mathrm{E} \\
22^{0} 15^{\prime} 53.51^{\prime \prime} \mathrm{N}\end{array}$ & $6.0 \mathrm{~km}$ & $\begin{array}{l}\text { The right river bank area is covered with } \\
\text { slums, open scrub lands and few urban } \\
\text { housing societies, whereas on the left banks; } \\
\text { agricultural fields are found. } \\
\text { A rain fed drainage merges into the river on } \\
\text { the left banks, this collects rainwater from } \\
\text { Sursagar, Dandiya Bajar and Manjalpur. }\end{array}$ & $\begin{array}{l}\text { Washing and liquor } \\
\text { distilleries (illegal). Also, } \\
\text { river waters are pumped } \\
\text { by local farmers for the } \\
\text { irrigation purpose. }\end{array}$ \\
\hline
\end{tabular}

Appendix 2. List of government, non government organizations and individuals involved in rescuing wild animals in and around Vadodara, Gujarat.

\begin{tabular}{|c|c|c|c|}
\hline & Name and address of organization & Name of the contact person & Contact number \\
\hline 1 & $\begin{array}{l}\text { Social Forestry, Forest Department, } \\
\text { New Anexie Building, Kothi, Vadodara }\end{array}$ & Conservator of Forest & $\begin{array}{l}\text { RFO-Sayajiaug (0265-27839542) } \\
\text { RFO-Padra (02662-24196) } \\
\text { RFO-Amod (02641-45359) }\end{array}$ \\
\hline 2 & Wildlife Circle - Forest Department, Kothi Office, Vadodara & Conservator of Forest & RFO-Harni (0265-2484499) \\
\hline 3 & Wildlife Circle- Bharuch, Forest Department & Conservator of Forest & RFO-Jambusar (02644-20294) \\
\hline 4 & Sayaji Baug Zoo, Maha Nagar Seva Sadan Vadodara & Zoo Curator & 0265-2784079 \\
\hline 5 & Fire Brigade, Maha Nagar Seva Sadan Vadodara. & Chief Fire Officer & 0265-2562010; 0256-2432050 \\
\hline 6 & $\begin{array}{l}\text { Vadodara Society for the Prevention of Cruelty to the Animals, } \\
\text { Vadodara City }\end{array}$ & Secretary & $0265-6555552$ \\
\hline 7 & $\begin{array}{l}\text { Gujarat Society for the Prevention of Cruelty to the Animals, } \\
60-\text { Kunj Society, Alkapuri, Vadodara }\end{array}$ & $\begin{array}{l}\text { Secretary: Snehal R. Bhavsar } \\
\text { Raj Bhavsar }\end{array}$ & $91-9825011117$ \\
\hline 8 & Let. Rohan Crocodile Charitable Trust, Raopura, Vadodara & $\begin{array}{l}\text { President \& Project Coordinator } \\
\text { Mr. Ashok Pawar / Rakesh V. }\end{array}$ & $\begin{array}{l}91-9825317472 \\
91-9925058137\end{array}$ \\
\hline 9 & Wildlife Reused Trust, Vadodara & President: Rajesh Kadam & $91-9662039281$ \\
\hline 10 & Canine Group, Vadodara City & President: Vishal Thakur & $91-9825683960$ \\
\hline 11 & Mr. Rohit Vyas and Group, Vadodara City & Mr. Rohit Vyas & $91-9998954023$ \\
\hline 12 & Mr. Kartik Upadhaya and Group, Vadodara. & Mr. Kartik Upadhaya & $91-9426270077$ \\
\hline 13 & Mr. Pravin Maharaj, Padra, Vadodara & Mr. Pravin Maharaj & $91-9327960226$ \\
\hline
\end{tabular}


of the United Nation, Field Document, i-iv+1-69pp.

Gujarat Pollution Board (2008). River Vishwamitri Water Analysis Results from Gujarat Pollution Board: 2007-08, http://gpcb.gov.in/projects.asp

Nathalie, N. (2011). Population of Nile Crocodiles (Crocodylus niloticus) in the northern part of park W. Niger. CSG Newsletter 30(1): 4-6.

Oza, G.M. (1975). Conservation of the crocodile in the Sayaji Sarovar lake, Baroda, India. Biology Conservation 7: 235236.

Vijaykumar, V. (1997). Evaluation of restocked Mugger crocodiles and its implication in long-term conservation and management of the species in Gujarat, India. July, 1997.VII - 65pp. Gujarat Institute of Desert Ecology, Patwadi Naka, Bhuj-Kachchh, Gujarat (Unpublished Report).

Vyas, R. (1993). Recent cases of man-eating by the Mugger (Crocodylus palustris) in Gujarat State. Hamadryad 18: 48-49.

Vyas, R. (2005). Recent notable incidences of conflict between Mugger and humans in Gujarat. CSG Newsletter 24(2): 7-8.

Vyas, R. (2010a). Mugger (Crocodylus palustris) population in and around Vadodara City, Gujarat State, India. Russian Journal of Herpetology 17(1): 43-50.

Vyas, R. (2010b). The Muggers (Crocodylus palustris) of Vishwamitri River: Past and Present. Report. Herpetology \& Environmental Research Project (HERP), Vadodara, India. 32pp, Figures 5, Tables 11, I-XX

Vyas, R. (2011). New threat on the Mugger (Crocodylus palustris) population of Vadodara city, Gujarat, India. CSG Newsletter 30(3): 15-16.

Vyas, R. \& S.R. Bhavsar (2009). Movement of an individual Mugger into urban areas of Vadodara City, Gujarat State, India. CSG Newsletter 28(3): 5-7.

Vyas, R. \& R. Vyas (2002). Mugger survey in the Vishwamitri River of Gujarat, India. CSG Newsletter 21(3): 9-110.

Whitaker, R. \& H. Andrews (2003). Crocodile conservation, Western Asia region: An update. Journal of the Bombay Natural History Society 100(2\&3): 432-445.

Whitaker, N, (2008). Survey of Human-crocodile conflict in Gujarat and Rajasthan: Trial of conflict mitigation education materials and further information on. Madras Crocodile Bank Trust, 30pp. (Unpublished Report). 